\title{
Studium przypadku dorosłego pacjenta jąkającego się od 5. roku życia - wpływ sposobu rozumienia patomechanizmu zaburzenia na stosowane strategie terapeutyczne
}

\section{Case study of an adult patient stuttering from the age of 5 years - effect of understanding of the pathomechanism of disorder on the choice of rehabilitation strategies}

\author{
Joanna Rostkowska \\ Instytut Fizjologii i Patologii Słuchu, Światowe Centrum Słuchu, Klinika Rehabilitacji, Warszawa/Kajetany \\ Adres autora: Joanna Rostkowska, Światowe Centrum Słuchu, Klinika Rehabilitacji, ul. Mokra 17, Kajetany, \\ 05-830 Nadarzyn, e-mail: j.rostkowska@ifps.org.pl
}

Streszczenie

Celem pracy jest omówienie teorii psychosomatycznego mechanizmu powstawania jąkania oraz zaprezentowanie programu rehabilitacyjnego wynikającego z rozumienia niepłynności mówienia jako objawu nerwicy. Autorka opisuje strategie i wynikające $\mathrm{z}$ nich metody terapeutyczne stosowane w czasie wieloletniej terapii wobec dorosłego pacjenta jąkającego się od 5. roku życia.

Słowa kluczowe: jąkanie • rehabilitacja • psychoterapia • terapia logopedyczna

Abstract

The aim of the study is to discuss the theory of the psychosomatic mechanism of stuttering and to present rehabilitation program based on understanding a speech disfluency as a symptom of neurosis. Author describes strategies and resulting therapeutical methods used in the long-term therapy of an adult patient stuttering since 5 years old.

Key words: stuttering • rehabilitation • psychotherapy • speech-language therapy

\section{Wprowadzenie}

W literaturze przedmiotu jąkanie definiowane jest zależnie od obszarów badawczych zainteresowań autorów. Definicje różnią się, ponieważ każda dyscyplina naukowa ma charakterystyczny dla siebie obszar badań i odrębne cele. Konstruowane są fizjologiczne, lingwistyczne, psychologiczne i socjologiczne definicje jąkania. Ich punktem stycznym jest niepłynność mówienia - warunek podstawowy do zaistnienia zaburzenia. Proponowane definicje skupiają się na objawach, odmiennie wyjaśniając patomechanizmy ich powstawania. W każdym podejściu do problemu widoczny jest ścisły związek między definicją (teorią) a terapią (praktyką).

Rozpatrując koncepcje jąkania pod kątem zaistniałego patomechanizmu, Tarkowski [1] wyodrębnił trzy nurty:

Teoria N - teoria somatopsychiczna. Przyczyna jąkania tkwi w aparacie mowy lub w sygnale mowy, a jej źródło znajduje się w mózgu. Niepłynność mówienia ma charakter organiczny i wynika z dyskoordynacji czasowo-motorycznej. Konsekwencją niepłynności mówienia są reakcje neurowegetatywne [2-4].

Teoria R - teoria psychosomatyczna. Przyczyna jąkania leży w psychice, a niepłynność mówienia jest jednym $\mathrm{z}$ objawów tłumionych emocji lub treści wypartych do podświadomości. Mechanizm jąkania można porównać do mechanizmu nerwicy [5-7].

Teoria N-R - teoria podkreślająca równorzędne znaczenie czynnika psychicznego i somatycznego w kształtowaniu się jąkania. Ważne jest tu wzajemne oddziaływanie czynników, czyli powstawanie interakcji między niepłynnością mówienia a indywidualnymi bądź społecznymi reakcjami towarzyszącymi $[8,9]$. 
Odpowiedzią terapeutyczną na teorię somatopsychiczną (Teoria N) jest terapia logopedyczna, której cel stanowi niwelowanie niepłynności mówienia i zmniejszenie stopnia logofobii [1] poprzez zastosowanie ćwiczeń: oddechowych, emisyjno-oddechowych, motoryki artykulacyjnej, startu mowy, rytmizacji wypowiedzi, a także technik relaksacji, wizualizacji $[10,11]$ oraz ćwiczeń z cyfrowym korektorem mowy [12]. Natomiast cele określone przez autorów teorii psychosomatycznych są realizowane w procesie psychoterapii. W piśmiennictwie dotyczącym jąkania psychoterapia jest nieprecyzyjnie definiowana, a jej stosowanie proponuje się logopedom $[1,13]$. Psychoterapię należy rozumieć jako specjalistyczną metodę leczenia polegającą na świadomym i zamierzonym stosowaniu zaprogramowanych oddziaływań psychologicznych niosących pomoc osobom z zaburzeniami psychogennymi. Celem psychoterapii są zmiany przejawiające się w zachowaniach, procesach poznawczych i emocjach pacjenta [14]. Osoba prowadząca psychoterapię nazywana jest psychoterapeutą. Kompetencje potrzebne do wykonywania zawodu nabywa w toku wieloletniego szkolenia dydaktycznego, licznych superwizji i własnej terapii [15].

W Polsce głównym propagatorem psychosomatycznego rozumienia podłoża jąkania jest Krzysztof Szamburski [7]. Według tego autora jąkanie jest zaburzeniem emocjonalnym (nerwicą), a jego objaw - niepłynność mówienia zostaje wyuczony i podtrzymywany po to, by osoba jąkająca mogła radzić sobie z lękiem. Szamburski uważa, że czynnik sprawczy jąkania to podstawowy konflikt nerwicowy, który kształtuje się pod wpływem działania sprzecznych norm społecznych, emocji bądź wymagań. Konflikt nie zostaje uświadomiony, ponieważ zagraża funkcjonowaniu psychicznemu i wiązałby się z przeżywaniem silnych emocji, takich jak: rozpacz, wściekłość, wstręt, przerażenie. Zaistniały konflikt nerwicowy wywołuje lęk, ponieważ niezależnie od podjętych działań rodzi duże napięcie emocjonalne. Zostanie ono skutecznie zredukowane przez wystąpienie objawu niepłynności mówienia. Niepłynność mówienia nie tylko zniweluje lęk, ale z oczywistych względów umożliwi wycofanie się z niechcianych działań lub sytuacji zagrażających, a niejednokrotnie doprowadzi do otrzymania potrzebnego wsparcia. W takiej sytuacji objawy niepłynności mówienia staną się rodzajem koła ratunkowego, niestety na krótko. Wraz z utrwalaniem się zaburzenia, pacjent uświadamia sobie znamienny wpływ jąkania na komunikatywność wypowiedzi słownych oraz funkcjonowanie społeczne. Stanie się to przyczyną wystąpienia lęku przed mówieniem (logofobia). Ostatecznie rozwinie się lęk wtórny, który spowoduje, że pacjent będzie postrzegać jąkanie jako główny czynnik dezorganizujący życie i źródło doświadczanych problemów w relacjach interpersonalnych.

Celem psychoterapii nerwicy (także z objawami w postaci niepłynności mówienia) w ujęciu psychoterapii integracyjnej [16] łączącej wiele systemów psychoterapeutycznych (psychodynamiczny, poznawczy, behawioralny, Gestalt) jest modyfikacja destrukcyjnych stylów życiowych [17], składających się $\mathrm{z}$ niesprzyjających adaptacji schematów poznawczych [18], emocji i zachowań, na takie style życiowe, które będą służyły zdrowiu psychicznemu pacjenta. Pobocznym efektem terapii będzie redukcja objawu niepłynności mówienia.

Proces psychoterapeutyczny, także osoby jąkającej się, rozpoczyna się od pracy terapeutycznej nad problemami funkcjonowania psychicznego i społecznego umiejscowionymi „tu i teraz” [19] w życiu pacjenta. Lęk wtórny powoduje, że pacjent „obwinia” jąkanie za większość swoich niepowodzeń, dlatego sam, w sposób naturalny, eksploruje ten obszar. Zadaniem terapeuty będzie pomoc w uświadomieniu sobie przez pacjenta, że niepłynność mówienia pełni rolę obronną, a rzeczywistą przyczyną problemów zdrowia psychicznego i funkcjonowania społecznego jest dotkliwy konflikt nerwicowy, którego korzenie najprawdopodobniej sięgają dzieciństwa. W ten sposób zostanie zredukowany lęk wtórny, który uniemożliwiał rozpoznanie pierwotnego lęku, związanego z podstawowym konfliktem. Dotarcie do źródła konfliktu (wgląd [16]) wiąże się najczęściej z ujawnieniem silnych, zazwyczaj negatywnych, emocji w stosunku do osób znaczących, które były jego przyczyną. Jest to moment niełatwy, ale pacjent odpowiednio wsparty przez psychoterapeutę będzie w stanie "przeżyć” doznaną w przeszłości krzywdę, wybaczyć i rozpocząć nowy etap w swoim życiu, wolny od destrukcyjnych schematów poznawczych, lęku i związanych z nim objawów niepłynności mówienia.

\section{Opis przypadku}

Mężczyzna, lat 27, informatyk, zgłosił się do lekarza foniatry z powodu nasilenia objawów jąkania, które nastąpiło w momencie rozpoczęcia pracy zawodowej. Pacjent jąka się od 5. roku życia bez uchwytnej przyczyny. Badania lekarskie nie wykazały nieprawidłowości w obrębie górnych dróg oddechowych. Pacjent został skierowany na konsultacje diagnostyczno-terapeutyczne do logopedy i psychoterapeuty (autorki artykułu, która jest neurologopedą i psychoterapeutą).

\section{Historia terapeutyczna}

Pacjent rozpoczął terapię logopedyczną w poradni psychologiczno-pedagogicznej, w wieku 7 lat, będąc w pierwszej klasie szkoły podstawowej. Logopeda stosował ćwiczenia kształtowania prawidłowego wzorca oddechowego, szczególnie wydłużenia fazy wydechowej oraz ćwiczenia zwalniania tempa mowy wraz z wykorzystaniem gestów rytmizacji $[10,11]$. Terapia odbywała się systematycznie, raz w tygodniu przez dwa lata. Pacjent nie pamięta, czy objawy jąkania zmniejszyły się. Wznowił terapię logopedyczną w 13. roku życia, w pierwszej klasie gimnazjum. Terapia, obejmująca ćwiczenia oddechowe, ćwiczenia delikatnego startu mowy oraz rytmizacji wypowiedzi, odbywała się systematycznie, raz w tygodniu, przez rok. Mężczyzna przypomniał sobie jeszcze dwie sytuacje życiowe (pierwsza klasa szkoły średniej oraz pierwszy rok studiów), w których odczuł potrzebę kontynuacji terapii logopedycznej. Niestety nie mogła się odbyć z powodu narastających obowiązków szkolnych. Pacjent samodzielnie wykonywał ćwiczenia głośnego czytania w zwolnionym tempie z towarzyszeniem gestu rytmizacji. Pytany o narzędzia wykorzystywane w diagnostyce logopedycznej przytoczył fragmenty „Próby sylabowej do oceny niepłynności mówienia” Kurkowskiego [20]. Pacjent nie posiadał żadnej dokumentacji przeprowadzonej diagnozy jąkania i prowadzonej terapii logopedycznej.

\section{Analiza historii terapeutycznej}

Z analizy historii terapeutycznej wynika, iż logopedzi pracujący z pacjentem rozumieli patomechanizm jąkania w sposób charakterystyczny dla podejścia somatopsychicznego 
(Teoria N). Stąd wykorzystanie kwestionariusza diagnostycznego Kurkowskiego, służącego do oszacowania (w procentach) poziomu niepłynności mówienia. Głównym celem terapii było zmniejszenie poziomu niepłynności mówienia dzięki zastosowaniu metod dostępnych logopedzie, takich jak: kształtowanie prawidłowego wzorca oddechowego, zwolnienie tempa mowy, gesty rytmizacji. Pacjent dobrowolnie uczęszczał na terapię logopedyczną przez trzy lata. Niestety objawy jąkania wciąż utrzymują się na dotkliwym poziomie, co oznacza, że prowadzona terapia logopedyczna nie dała oczekiwanego rezultatu w postaci redukcji niepłynności mówienia do akceptowalnego poziomu. Pacjent poszukiwał wsparcia w terapii logopedycznej w okresach występowania nasilonych emocji związanych z rozpoczęciem kolejnego etapu życiowego. Tak było i tym razem. Pacjent nie łączył w swojej świadomości problemu jąkania się $\mathrm{z}$ funkcjonowaniem psychicznym.

\section{Nowy program rehabilitacyjny}

Brak wymiernych efektów wieloletniej terapii logopedycznej pozwala na postawienie tezy o psychosomatycznym mechanizmie jąkania (Teoria R), a to daje możliwość opracowania nowego programu rehabilitacyjnego. Zgodnie $\mathrm{z}$ Teorią $\mathrm{R}$ psychoterapeuta (J.R.) postawił tezę, że niepłynność mówienia jest $\mathrm{w}$ tym przypadku jednym $\mathrm{z}$ objawów nerwicy [21]. Nowy plan rehabilitacji będzie realizowany przez interdyscyplinarny zespół złożony z psychoterapeuty i logopedy, zgodnie $z$ postulatami o potrzebie prowadzenia wielokierunkowych działań w terapii osób jąkających $[1,10,13]$.

Trzonem planowanej rehabilitacji stanie się psychoterapia, w założeniach oparta na rozważaniach Szamburskiego [21]. Celem psychoterapii będzie modyfikacja schematów poznawczych oraz emocji i zachowań negatywnie wpływających na funkcjonowanie psychiczne pacjenta. Cel zostanie osiągnięty dzięki uchwyceniu i przepracowaniu konfliktu podstawowego. Efektem psychoterapii będzie ukształtowanie nowych, sprzyjających rozwojowi, złożonych i elastycznych schematów poznawczych $[18,22]$ i dostosowanych do nich emocji i zachowań. Zostanie zredukowany lęk, a co za tym idzie - zmniejszy się niepłynność mówienia jako objaw nerwicy. Celem terapii logopedycznej będzie zredukowanie niepłynności mówienia poprzez ćwiczenia $\mathrm{z}$ użyciem echokorektora. Zadania logopedy ograniczą się do okresowych konsultacji związanych ze zmianą ustawień echokorektora i wskazówek dotyczących samodzielnej pracy w domu przy użyciu tego urządzenia.

Pacjent wyraził świadomą zgodę [19] na uczestnictwo w psychoterapii. Bezpośrednim powodem poszukiwania pomocy psychoterapeutycznej była obawa pacjenta, że z powodu jąkania nie zostanie zaakceptowany w nowym środowisku społecznym. Dlatego w czasie pierwszych sesji terapeutycznych zadaniem mężczyzny było określenie wpływu niepłynności mówienia na emocje, myślenie i zachowanie. Pacjent upatrywał w jąkaniu głównego źródła niepowodzeń związanych z edukacją i kontaktami społecznymi. Mimo faktów (ukończone dwa kierunki studiów, rosnące grono przyjaciół, stała partnerka życiowa) oceniał negatywnie swoje dotychczasowe osiągnięcia życiowe. Pytany, w jakich sytuacjach komunikacyjnych objawy niepłynności mówienia przybierają na sile, wymienił rozmowę z ojcem i matką oraz prezentowanie przygotowanej mowy wobec znanego i nieznanego audytorium. W czasie rozmów $\mathrm{z}$ rodzicami pacjentowi stale towarzyszy myśl, że ich zawiódł. Myśl ta wywołuje lęk i smutek. Te informacje pozwoliły na przyjęcie hipotezy dotyczącej podstawowego konfliktu związanego z wygórowanymi oczekiwaniami rodziców wobec syna (brak akceptacji). Mierzenie się z odrzuceniem i doświadczanie lęku było najprawdopodobniej ponad siły pacjenta, a jedynym sposobem obrony, w obliczu podstawowego konfliktu, było zaistnienie obiektywnych trudności. Stały się nimi objawy niepłynności mówienia. Ich celem było zmniejszenie lęku związanego z oczekiwaniami rodziców (w efekcie akceptacja dziecka). W percepcji dziecka objawy niepłynności mówienia nie wartościowały go ujemnie, a były obiektywną trudnością. Zastosowanie odpowiednich technik psychoterapeutycznych (np. dialog sokratejski [22]) pozwoliło pacjentowi zrozumieć, że to nie jąkanie jest powodem niepowodzeń życiowych. Niepłynność mówienia pełni rolę kurtyny, za którą kryje się rzeczywista przyczyna ciągłego niezadowolenia z siebie i stale towarzyszącego lęku. Podjęty przez pacjenta wątek unikania rozmów z ojcem i matką dał początek nowej eksploracji i pozwolił na analizę relacji rodzinnych, uzyskanie wglądu i dotarcie do podstawowego konfliktu, który tkwi w relacji ojciec - syn. Pacjent, będąc kilkuletnim dzieckiem, nie potrafił sprostać oczekiwaniom ojca i towarzyszącym im emocjom, dlatego pojawiły się objawy niepłynności mówienia. Spełniły swoją rolę, ponieważ spowodowały zmniejszenie oczekiwań ojca wobec syna, ale szybko się utrwaliły i zaczęły stanowić główny problem jego funkcjonowania. Moment rozpoczęcia terapii logopedycznej zbiegł się w czasie z rozpoczęciem edukacji w szkole podstawowej i związanymi z tym etapem nowymi wymaganiami wobec dziecka. Wymagania stawiane przez ojca także wzrosły, pacjent znów nie potrafił im podołać i niepłynność mówienia utrwalała się. Obecnie pacjent pracuje z psychoterapeutą nad relacją z ojcem. Zadaniem pacjenta jest dostrzeżenie krzywdy wyrządzonej przez ojca (brak akceptacji) i wybaczenie mu. Jest to trudny emocjonalnie proces, ponieważ polega na skontaktowaniu się z własnym lękiem, cierpieniem, gniewem i smutkiem [23]. Kolejnym etapem będzie praca psychoterapeutyczna nad relacją z matką, ponieważ pacjent zaczął dostrzegać, że nie wpłynęła ona na zachowania ojca. Przepracowanie relacji z ojcem i z matką (np. rozmowa z pustym krzesłem [16]) umożliwi pacjentowi podjęcie pracy psychoterapeutycznej z krytykiem wewnętrznym [16] wywołującym niskie poczucie własnej wartości. Powodem ciągłego niezadowolenia ze swoich osiągnięć są negatywne przekonania, które pacjent ma o sobie. Przekonania te są traktowane przez niego jak własne, chociaż w rzeczywistości ich autorami są rodzice. Rozpoznanie pochodzenia negatywnych przekonań ułatwi pacjentowi uwolnienie się od nich i zastąpienie ich własnymi, realniejszymi ocenami i pewnością siebie.

Rezultatem procesu psychoterapeutycznego będzie zmniejszenie wpływu podstawowego konfliktu nerwicowego, związanych z nim emocji i zachowań na funkcjonowanie pacjenta oraz możliwość ukształtowania nowego stylu życia [17]. Pewnej redukcji ulegnie objaw nerwicy, którym w tym przypadku jest niepłynność mówienia.

Trudno określić, czy zaproponowany program rehabilitacji zakończy się sukcesem. Co w tym przypadku będzie miarą sukcesu? Warto rozmawiać z pacjentem o jego oczekiwaniach, bo odpowiedź na to pytanie będzie ulegać zmianom w toku rehabilitacji. 


\section{Piśmiennictwo:}

1. Tarkowski Z. Jąkanie. Warszawa: Wydawnictwo Naukowe PWN; 2002

2. Richter E. Fizjopatologiczne podłoże jąkania. Logopedia, 1967; 6: 21-33.

3. Schwartz M. The core of the stuttering block. J Speech Hear Dis, 1986; 39: 169-78.

4. Szeląg E. Neuropsychologiczne podłoże jąkania - przegląd badań empirycznych nad asymetrią funkcjonalną mózgu. Kosmos, 1995; 44: 199-214.

5. Fernau-Horn H. Die Sprechneurosen. Stuttgart: Aulf Hipokrates; 1973.

6. Grzybowska A. Behawioralne teorie jąkania. Przegląd Psychologiczny, 1987; 1: 26-37.

7. Szamburski K. Patomechanizm powstawania jąkania rozwojowego - propozycja powiązania jąkania z lękiem. Logopedia, 2006; 2(3): 41-57.

8. Engiel Z. Próba opracowania systemu ćwiczeń logopedycznych w rehabilitacji jąkania. Zagadnienia wychowawcze a zdrowie psychiczne, 1977; 3: 70-1.

9. Grabias S. Typologia zaburzeń mowy. Narastanie refleksji logopedycznej. Logopedia, 1996; 23: 79-90.

10. Szkiełkowska A, Ratyńska J, Czyżewski A i wsp. Schemat postępowania terapeutyczno-rehabilitacyjnego u osób jąkających się. Otolaryngologia Polska, 2003; LVII(4): 555-9.

11. Mularzuk M, Szkiełkowska A, Kurkowski ZM i wsp. Program postępowania terapeutyczno-rehabilitacyjnego wobec pacjentów jąkających się. Now Audiofonol, 2012; 1(1): 94-9.

12. Adamczyk B. Terapia jąkania metodą Echo. W: Gałkowski T, Tarkowski Z, Zaleski T, red. Diagnoza i terapia zaburzeń mowy. Lublin: Wydawnictwo UMCS; 1993.
13. Chęciek M. Jąkanie. Diagnoza - Terapia - Program. Kraków: Oficyna Wydawnicza „Impuls”; 2007.

14. Grzesiuk L, red. Psychoterapia. Szkoły, zjawiska, techniki i specyficzne problemy. Warszawa: Wydawnictwo Naukowe PWN; 2002.

15. Frank JD, Frank JB. Perswazja i uzdrawianie: analiza porównawcza psychoterapii. Warszawa: Instytut Psychologii Zdrowia; 2005.

16. Prochaska JO, Norcross JC. Systemy psychoterapeutyczne. Analiza transteoretyczna. Warszawa: Instytut Psychologii Zdrowia; 2006.

17. Adler A. Sens życia. Warszawa: Państwowe Wydawnictwo Naukowe; 1986.

18. Preston J. Zintegrowana terapia krótkoterminowa. Gdańsk: Gdańskie Wydawnictwo Psychologiczne; 2005.

19. Yalom ID. Dar terapii. List otwarty do nowego pokolenia terapeutów i ich pacjentów. Warszawa: Instytut Psychologii Zdrowia; 2003.

20. Kurkowski Z. Próba do oceny niepłynności mówienia. Warszawa: Instytut Fizjologii i Patologii Słuchu; 2003.

21. Szamburski K. Nerwica jąkania - inny sposób spojrzenia na problem niepłynności mówienia. Logopedia, 1996; 23: 191-214.

22. Beck JS. Terapia poznawcza. Podstawy i zagadnienia szczegółowe. Kraków: Wydawnictwo Uniwersytetu Jagiellońskiego; 2005.

23. Mellibruda J. Pułapka niewybaczonej krzywdy. Warszawa: Instytut Psychologii Zdrowia; 1999. 